\title{
Surfactant can be supplemented before the neonate needs it
}

\author{
Goran Enhorning
}

Children's Hospital of Buffalo, Department of Gynecology and Obstetrics, State University of New York at Buffalo, New York, U.S.A.

Today, there is good evidence that neonatal respiratory distress syndrome (RDS) can be prevented, to some extent, and be treated by instilling surfactant into the trachea, thus replacing what the preterm neonate is seriously missing. Before discussing the most recent experiences, however, allow me to go back in time and look at some of the events that lead up to the situation of today. The surfactant story starts with vON NEERGAARD who was far ahead of his time and whose publication of 1929, as a result, was met with very little understanding and interest [18]. By replacing all the air in the lungs of an animal with a liquid, VON NEERGAARD described how he could turn back the clock and return the lungs to the situation they were in when the animal had just been born, and had not yet taken its first breath. Expanding the air-free lungs with a liquid, vON NEERGAARD found, required considerably less pressure than expanding them with air. He drew the conclusion that, when air was the expanding medium, the added resistance was due to surface tension in the many air liquid interfaces of the airways. That was basically vON NEERGAARD's contribution. When nobody responded to his publication, not in Switzerland where he lived nor anywhere else in the world, he left the subject for good.

Almost twenty years later, PETER GRuENwald [14] rediscovered the importance of surface tension as something resisting the first breath of an infant. GRUENWALD's experiments were similar to those of VON NEERGAARD. He found that expanding the lungs of a preterm stillborn infant with air required more pressure than expanding the lungs with saline, but the pressure required for aeration was reduced if a surface active agent was added to the liquid in the airways. That clearly demon- strated that surface tension was resisting aeration; the more surface tension was lowered with the surface-active agent, the easier was the aeration.

The lungs of an infant dying shortly after birth, who never got the lungs expanded, will often show that the air had moved down through the wider airways, but was stopped when the airways became narrower. Air moving into a liquid-filled tube is resisted by surface tension and that resistance is greater the narrower the tube. A wellknown method of determining surface tension of a liquid is to measure the height to which a liquid rises in a narrow glass tube (figure 1). Suppose we use that method and enclose the lower end of the glass tube. The enclosed space has been given the shape of a thorax. If pressure is lowered in this "thorax" by the "diaphragm" moving down, the meniscus can be pulled down to the level of the surrounding liquid. The force required to hold the meniscus at that level, where gravity is of no consequence, is the pressure difference across the meniscus, $\Delta \mathrm{P}$, times the cross section of the tube, $\pi R^{2}, R$ being the radius of the tube lumen. That force is counteracted by surface tension of the airway liquid, $\gamma$, acting along the inner circumference of the tube, $2 \pi R$. We, thus, get

$\Delta \mathrm{P} \cdot \pi \mathrm{R}^{2}=\gamma \cdot 2 \pi \mathrm{R}$,

from which we delete $\pi$ and an $\mathrm{R}$ on each side of the equal sign and end up with the simple equation,

$\Delta \mathrm{P}=2 \gamma / \mathrm{R}$,

the Law of Laplace. This law tells us that the resistance to the first breath, which is due to surface tension, is directly in proportion to $\gamma$, surface tension of the airway fluid, and inversely 


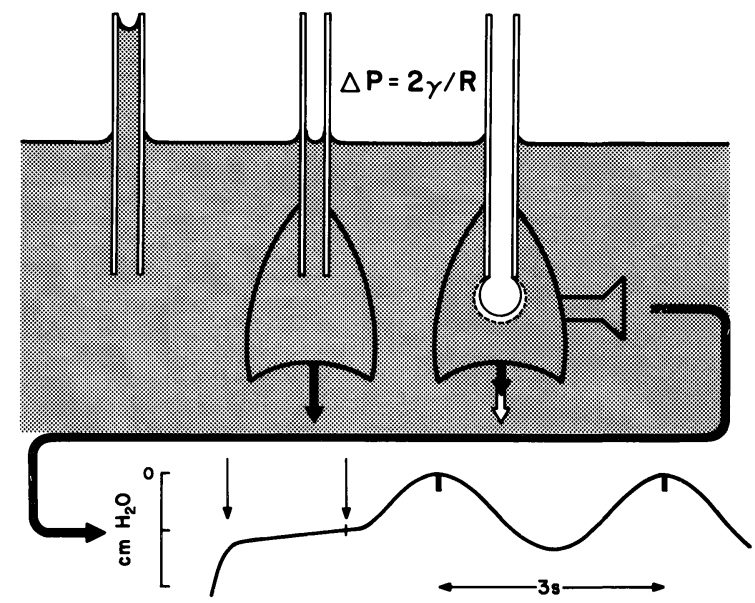

Figure 1. Liquid in narrow glass capillary rises because of surface tension (left). If the lower end of the capillary is enclosed and pressure is reduced so that the air-liquid interface comes down to the level of the surrounding liquid (center), the pressure difference, $\Delta \mathrm{P}$, is counteracting surface tension only. The Law of Laplace, $\Delta \mathrm{P}=$ $2 \gamma / \mathrm{R}$, can then be derived (see text). If the volume is reduced further and is oscillating (right), pressure around the bubble can be recorded. The bubble is not pulsating between vertical arrows but maintained at maximal size. The mark at the peaks of the tracing indicates minimal bubble size.

related to the airway radius, $\mathrm{R}$. When GRUENWALD lowered the value of $\gamma$ by adding a surfaceactive agent, he reduced resistance to aeration, and the air-liquid interfaces could move more readily through the finer terminal airways.

Suppose we lower pressure further. We then overcome the effect of gravity and the meniscus moves down to the lower end of the tube. Then, as a bubble suddenly expands, $\Delta \mathrm{P}$ is instantaneously reduced, obvisouly because the radius has enlarged. Suppose we were to make the bubble "breathe" by moving the diaphragm up and down. A dilemma would then became obvious; the transmural pressure required to keep a small bubble expanded would be greater than that needed for a large bubble. In the lung, the situation is just the opposite. Pattle in England was the first person who helped clarify this dilemma [19]. He found that bubbles squeezed from the cut surface of the lung could be very small; yet, the gas inside the bubbles, which ought to be under high pressure, was not quickly absorbed by the surrounding liquid. Instead, the bubbles could be observed through a microscope for a long time. Pattle concluded that the lung must produce a substance that forms a film in the bubble's air-liquid interface, lowering surface tension to very low values, so that pressure inside the bubble is hardly higher than outside and yet the radius is small.

Using the modified Wilhelmy balance, CLEMENTS clarified PATTLE's experiments [2]. He found the substance produced by the lung would lower surface tension to close to zero, and when the film was expanded again, surface tension would increase to about $40 \mathrm{mN} / \mathrm{m}$. Clements concluded that this changing surface tension would stabilize the lung and prevent the alveolus from collapsing when it was diminishing in size during expiration. When the main component of surfactant, dipalmitoyl phosphatidylcholine (DPPC), was studied with this instrument, the tracing obtained was similar to that of pulmonary surfactant; very low surface tension was obtained with film compression. For this reason, it was not surprising that, when it had been reported by AVERY and MEAD that infants dying from RDS had a surfactant deficiency, attempts were made to treat the condition by replacing the missing surfactant, using only the main component, DPPC. This was done by a team in Canada [20], and by CHU et al. [3], from San Francisco, who went to Singapore to carry out their clinical trial. The results of these two studies were not encouraging. DPPC alone did not seem to cure RDS.

At that time, my collaborators and I had developed another method for studying the surface properties of pulmonary surfactant: the pulsating bubble surfactometer [1, 4]. Its principle is to measure pressure around a bubble expanded in the liquid to be evaluated. The bubble, like an alveolus, communicates with ambient air and is made to pulsate while the pressure is recorded (figure 1). When the sample consists of natural surfactant, obtained from a saline lavage of adult animals' airways, a monomolecular film will quickly form. When the bubble is approaching minimal size and the surface film molecules are forced to come closer together, however, the pressure difference across the bubble surface, $\Delta \mathrm{P}$, is almost zero. When the bubble is coming to its maximal size, $\Delta \mathrm{P}$ is about $1.5 \mathrm{~cm}$ water. With the Law of Laplace, it can be calculated that, at minimal size, surface tension is close to zero. At maximal size, when the bubble has a radius of $0.55 \mathrm{~mm}$, surface tension is $30-35 \mathrm{mN} / \mathrm{m}$, thus in fair agreement with values found with the Wilhelmy balance. On the other hand, DPPC, when 
studied alone in suspension, requires a very long time to form a monolayer at the bubble's surface. When DPPC was studied with the Wilhelmy balance, it had been dissolved in hexane and the solution had been spread over the water in the trough. When the hexane had evaporated, the film was ready for study. That was very different from the way the film can be expected to form in the lung of a neonate. In other words, we found with the pulsating bubble surfactometer, that the adsorption rate for DPPC alone was far too low; whereas, a film would form almost instantaneously with natural surfactant. This made us believe that the principle of surfactant replacement was sound and we were encouraged to carry out a number of animal experiments $[5,7,8]$. They proved to us that the preterm neonate, who is at great risk of developing RDS, with surfactant supplementation prior to the first breath, will have a facilitated and even expansion of the lung. This, in turn, resulted in increased survival rate.

We then tried the principle of surfactant supplementation prior to the first breath with a series of experiments on Rhesus monkies [6]. Six of the primate neonates were delivered at approximately 130 days and treated with surfactant. An additional six were delivered at the same gestational age and served as controls. The monkey neonates were treated as intensely as human premature neonates would be, i.e., the respiratory support was altered depending on the results of frequent blood gas analysis. We found that $\mathrm{FiO}_{2}$ could be clearly lowered in the treated animals. Yet, their hypoxia was less and their survival was improved.

The monkey experiments were certainly encouraging, but we were not ready for a clinical trial since the surfactant preparation we had used had a high protein content $(\sim 10 \%)$ and was not sterile. Any attempt to sterilize resulted in loss of surface activity. We found, however, that the lipids that could be extracted from natural surfactant, after reextraction and acetone precipitation had a protein content of less than $1 \%$, and formed an active preparation when resuspended in an electrolyte solution. That preparation tolerated sterilization by autoclaving. We were then ready for a clinical trial, but we were not to be the first. As much as four years had elapsed since FUJIWARA et al. [11] reported their successful surfactant treatment of infants with severe RDS.

Our aim was to prevent, and not to treat, RDS by supplying surfactant before it was needed. If deposited in high concentrations in the upper airways before the first breath, the surfactant would be acting, from the very beginning, right where it was needed, at the air-liquid interface. It would lower resistance to the first breath and automatically be evenly distributed. A monolayer film would be left outlining the alveoli and, most importantly, the cylindrical airways. With early administration, prior to the first breath, damage to the airway epithelium should be possible to avoid since respirator pressures could be lower and the need for extra oxygen would be less. The surfactant preparation we used was prepared from the lipids that could be extracted from a calf lung lavage.

We restricted our study [9] to infants born at a gestational age of less than 30 weeks. Those born $27-29$ weeks received $4 \mathrm{ml}$ surfactant, i.e., 100 mg phospholipids, and those born before 27 weeks received $3 \mathrm{ml}$, i.e., $75 \mathrm{mg}$ phospholipids. Each infant was intubated immediately after birth and the first breath was inhibited until surfactant, or air for the controls, had been deposited through the tracheal tube. Following two or three manual inflations with a bag, the infant was connected to a respirator, the setting of which was guided by the results of the blood gas analysis. The study that was randomized went on for a year. It showed that, of the 39 infants who had received surfactant, only 1 died neonatally; whereas, of the 33 controls, six died.

The infants receiving surfactant clearly benefited: They required less oxygen and their ventilation index, the peak inspiratory pressure times frequency, could be kept lower. Our experiences are in accord with those of others using a preparation from calf lung lavage $[15,21]$, with those using human surfactant $[16,17]$, and with those administering surfactant TA $[10,11,13]$ the preparation originally described by FuJIWARA et al. [12]. The total picture is clear: surfactant instillation will help prevent or quickly alleviate RDS.

\section{Summary}

Pulmonary surfactant is a complex mixture, but clearly has one main component, dipalmitoylphosphatidylcholine, or DPPC. The respiratory distress syndrome, RDS,

a condition afflicting the baby born too early, is caused by a deficiency of pulmonary surfactant. When this was first realized, attempts were made to treat the condition 
by supplying DPPC, the main component of the missing surfactant. These first attempts to supplement the pulmonary surfactant were unsuccessful, however, and with the bubble surfactometer, it is clearly seen that DPPC alone does not have the needed surface properties. The adsorption rate is too low, i. e., DPPC only is very slow in forming a film at the air-liquid interface. Natural surfactant on the other hand has the capacity to form a film instantaneously. Therefore, if natural surfactant is supplied in the upper airways prior to the first breath, it will immediately upgrade the maturity of the neonate's lungs; aeration is facilitated and the lungs are given stability.

With a surfactant preparation, consisting of the lipids extracted from calf lung lavage, a randomized clinical trial was carried out on infants at particularly high risk of developing RDS. Of the 39 infants receiving surfactant prior to the first breath after birth, only one died neonatally; whereas, of the 33 controls, six died.

Keywords: Bubble Surfactometer, dipalmitoylphosphatidylcholine (DPPC), respiratory distress syndrome (RDS), surfactant supplementation.

\section{Zusammenfassung}

Der Surfactant kann zugeführt werden, bevor das Neugeborene ihn benötigt

Der Lungensurfactant ist eine komplexe Mischung, hat aber eine Hauptkomponente, das Dipalmitoylphosphatidylcholin oder DPPC. Dem Atemnotsyndrom oder RDS als Komplikation des Frühgeborenen liegt ein Mangel an Surfactant zugrunde. Nachdem dies bekannt war, versuchte man, ein RDS mit DPPC zu behandeln. Es ließen sich keine Erfolge erzielen und mit dem Schaum-Surfactometer läßt sich nachweisen, daß DPPC allein nicht die geforderten Oberflächeneigenschaften besitzt. Die Adsorption erfolgt zu langsam oder anders ausgedrückt, DPPC bildet nur sehr langsam einen Film an der Grenzschicht zwischen Luft und Flüssigkeit. Ein natürlicher Surfactant kann dagegen sofort einen solchen Film herstellen. Wird vor dem ersten Atemzug natürlicher Surfactant in die oberen Luftwege gegeben, kann sofort die Lungenreife beeinflußt werden; die Belüftung und die Stabilität der Lungen werden verbessert. Mit einer speziellen Surfactantlösung, die extrahierte Lipide aus Lavagen von Kalbslungen enthielt, wurde eine randomisierte klinische Studie bei Kindern mit hohem Risiko für die Entwicklung eines RDS durchgeführt. Von den 39 Kindern, die den Surfactant vor dem ersten postnatalen Atemzug erhielten, starb nur eines, während von den 33 Kontrollkindern sechs starben.

Schlüsselwörter: Dipalmitoylphosphatidylcholin (DPPC), RDS, Schaum-Surfactometer, Surfactantersatz.

\section{Résumé}

L'apport de surfactant peut être effectué avant que le nouveau-né le nécessite

Le surfactant pulmonaire est un mélange complexe, mais à l'évidence il possède un composant principal, le dipalmitoylphosphatidylcholine ou DPPC. Le syndrome de détresse respiratoire, SDR, pathologie touchant le nouveau-né né trop tôt, est provoqué par un déficit en surfactant pulmonaire. Lorsqu'on réalisa celà pour la première fois, des essais ont été entrepris pour traiter cette pathologie en ajoutant le DPPC, le composant principal du surfactant manquant. Ces premières tentatives pour ajouter du surfactant pulmonaire furent infructueuses, néanmoins, à l'aide du surfactomètre à bulle, il apparaît clairement que le DPPC tout seul n'a pas les propriétés de surface recherchées. Le taux d'absorption est trop faible, c'est-à-dire que le DPPC seul est trop lent pour établir un film à l'interface airliquide. Le surfactant naturel, à l'inverse, a la capacité de former un film instantanément. C'est ainsi que si on apporte du surfactant naturel dans les voies aériennes supérieures avant la première respiration, il améliorera immédiatement la maturité des poumons du nouveau-né; l'aération est facilitée et les poumons acquièrent une stabilité.

A l'aide d'une préparation de surfactant, comprenant des lipides extraits de lavages pulmonaires de veaux, un essai clinique randomisé a été réalisé chez des enfants hautement à risque de développer un SDR. Sur les 39 enfants ayant reçu du surfactant avant la première respiration après la naissance un seul est décédé en période néonatale; tandis que six sont morts sur les 33 témoins.

Mots-clés: Apport de surfactant, dipalmitoylphosphadidylcholine (DPPC), surfactomètre à bulle, syndrome de détresse respiratoire (SDR). 


\section{References}

[1] AdAms FH, G ENHORnING: Surface properties of lung extracts. I. A dynamic alveolar model. Acta Physiol Scand 68 (1966) 28

[2] Clements JA: Surface phenomena in relation to pulmonary function. Physiologist 5 (1962) 11

[3] Chu J, JA Clements, EK Cotton, MH Klaus, AY SWEET, WH TOOLEY: Neonatal pulmonary ischemia. I. Clinical and physiological studies. Pediatrics 40 (1967) 709

[4] Enhorning G, FH Adams: Surface properties of fetal lamb tracheal fluid. Am J Obstet Gynecol 92 (1965) 563

[5] Enhorning G, G Grossman, B Robertson: Tracheal deposition of surfactant before the first breath. Am Rev Respir Dis 107 (1973) 921

[6] Enhorning G, D Hill, G Sherwood, E Cutz, B ROBERTSON, C BRYAN: Improved ventilation of prematurely-delivered primated following tracheal deposition of surfactant. Am J Obstet Gynecol 132 (1978) 529

[7] ENHORNING G, B RoBERTSON: Lung expansion in the premature rabbit fetus after tracheal deposition of surfactant. Pediatrics 50 (1972) 58

[8] ENHORNInG G, B Robertson, E Milne, R WAGNER: Radiological evaluation of the premature rabbit neonate after pharyngeal deposition of surfactant. Am J Obstet Gynecol 121 (1975) 475

[9] Enhorning G, A Shennan, F Possmayer, M Dunn, C Chen, J Milligan: Prevention of neonatal respiratory distress syndrome by tracheal instillation of surfactant: a randomized clinical trial. Pediatrics 76 (1985) 145

[10] FujIwARA T: Surfactant replacement in neonatal RDS. In: ROBERTSON B, LMF VAN GOLDE, JJ BATENBURG (eds): Pulmonary Surfactant. Elsevier Science Publishers, Amsteram 1984

[11] Fujiwara T, H Maeta, S Chida, T Morita, Y WATABE, T ABE: Artificial surfactant therapy in hyaline-membrane disease. Lancet 1 (1980) 55

[12] FujIwara T, Y TANAKa, T TAKeI: Surface properties of artificial surfactant in comparison with natural and synthetic surfactant lipids. IRCS Med Sci 7 (1979) 311

[13] Gitlin JD, RF Soll, RB Parad, JD Horbar, HA Feldman, JF LUCEY, HW TAEUSCH: Randomized controlled trial of exogenous surfactant for the treatment of hyaline membrane disease. Pediatrics 79 (1978) 31

[14] Gruenwald P: Surface tension as a factor in the resistance of neonatal lungs to aeration. Am J Obstet Gynecol 53 (1947) 996

[15] KWong MS, EA Egan, RH NotTer, DL Shapiro: Double-blind clinical trial of calf lung surfactant extract for the prevention of hyaline membrane disease in extremely premature infants. Pediatrics 76 (1985) 585

[16] Merritt TA, M Hallmann, BT Bloom, C Berry, K BenirschKe, D SAHN, T Key, D EDWARDS, A JarvenpaA, M PoHJavouri, K KankaAnpaA, M KunNas, H PaAtero, J Rapola, J JaAskelainen: Prophylactic treatment of very premature infants with human surfactant. N Engl J Med 315 (1986) 785

[17] Merritt TA, M Hallman, K Holcomb, D Strayer, B Bloom, S Revak, C Cochrane: Human surfactant treatment of severe respiratory distress syndrome: pulmonary effluent indicators of lung inflammation. J Pediatr 108 (1986) 741

[18] NeEgaARD K von: Neue Auffassung über einen Grundbegriff der Atemmechanik. Z Ges Exp Med 66 (1929) 373

[19] Pattle RE: Properties, function, and origin of the alveolar lining layer. Proc R Soc Lond [Biol] 148 (1958) 217

[20] Robillard E, Y Alaire, P Dagenias-Perusse, E Baril, A GuIlbeault: Microaerosol administration of synthetic $\beta$ - $\gamma$-dipalmitoyl-L- $\alpha$-lecithin in the respiratory distress syndrome: a preliminary report. Can Med Assoc J 90 (1964) 55

[21] Shapiro DL, RH NotTer, FC Morin, KS Deluga, LM Golub, RA Sinkin, KI Weiss, C Cox: Doubleblind, randomized trial of a calf lung surfactant extract administered at birth to very premature infants for prevention of respiratory distress syndrome. Pediatrics 76 (1985) 593

Goran Enhorning, M.D.

State University of New York at Buffalo Department of Gynecology and Obstetrics Children's Hospital of Buffalo 219 Bryant Street Buffalo, New York 14222, U.S. A. 


\section{Schneider · Stroiñski \\ Comprehensive $B_{12}$ \\ Chemistry · Biochemistry - Nutrition Ecology · Medicine}

1987. $18 \mathrm{~cm}$ x $26 \mathrm{~cm}$. XII, 409 pages, numerous illustrations.

Hardcover. DM 290,-; approx. US \$160.00

ISBN $311008239 \mathrm{X}$

This book is addressed to clinicians and advanced students in different areas such as chemists, biochemists, pharmacologists, nutritionists, animal breeders, ecologists and marine biologists who wish to extract essential information on particular aspects of vitamin $B_{12}$.

Most of the data presented are accompanied by references to the original literature and are preceded by a brief and comprehensive introduction.

Some techniques which at present are of interest to a wider group of researchers such as immobilization of vitamin $B_{12}$ on supports, methods of $B_{12}$ assay and biological or chemical synthesis of various $B_{12}$ analogues are described in detail.

\section{Contents in brief}

Historical outline - Nomenclature of Corrinoids - Chemistry of Cobalamin and Related Compounds - Biosynthesis of Vitamin $\mathrm{B}_{12}$. Purification and Estimation of Vitamin $B_{12}$. The Occurrence and Distribution of Corrinoids - Cobamide Dependent Enzymes - Non-Enzymatic Vitamin $B_{12}$ Binding Proteins in Man and Animals - Medical Aspects of Vitamin $\mathrm{B}_{12}$. Index of Species - Subject Index

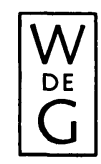

de Gruyter - Berlin - New York 